\title{
Juliusz Engelhardt
}

Prof. zw. dr hab.

Uniwersytet Szczeciński, Wydział Zarządzania i Ekonomiki Usług

juliusz.engelhardt@wzieu.pl

DOI: 10.35117/A_ENG_18_06_08

\section{Calculation of access charges for rail infrastructure in the light of European Union's regulations}

\begin{abstract}
The article presents evolution of EU's regulations referring to the rules of calculation of access charges for rail infrastructure. In the opposite to payable utilization of road, harbor or airport infrastructure, payable access to the rail infrastructure for transport operators (rail carriers) is a relatively new issue in the European railways, because it emerged just in 1991 in relation with taken up system reforms of EU's rail sector. In the introductory part of the article, the Directive 91/440 has been indicated as a historically first law act that referred to the issue of calculation of access charges for rail infrastructure. Next, there were presented regulations of the Directive 2001/14 adopted within so called first railway package and vagueness in their interpretation, which led to the trials before the European Court of Justice, whereas the most important was the one against Poland, ended with the sentence on the 30th of May 2013. The final part of the article presents references to this sentence and to the new regulations referring to the charges for the access to rail infrastructure, included in the Directive 2014/34 and executive ordinance 2015/909 issued on its basis.
\end{abstract}

Keywords: Rail infrastructure; Charges; Charges differentiating

\section{Introduction}

The rules for calculating the access rates to the railway infrastructure have been set for the first time in Directive 91/440 on the development of the community railways adopted in July 1991. Article 8 of the said Directive stated that "The infrastructure manager shall charge a fee for the use of the railway infrastructure for which it is responsible. The fees are borne by railway undertakings and international groups using the infrastructure. After consulting the management unit, Member States shall lay down rules on the determination of such a charge. ' Establishing the principle of paid use of railway infrastructure in 1991 was one of the pillars of the new European Union policy in the railway sector and was obviously connected with another pillar of this policy in the form of establishing the principle of separation of railway infrastructure management function from the operation function (transport operations) in enterprises rail. Directive $91 / 440$ only in a very general way referred to the principles of calculating the fee for access to infrastructure, through a rather laconic statement in the aforementioned art. 8, that "a user fee that is calculated in a way that avoids discrimination of railway undertakings may, in particular, take account of the number of kilometers, train composition and any specific requirements such as speed, axle load and grade or period of use".

After the entry into force of Directive 91/440, in 1992-1995, there were many practical problems and difficulties related to the implementation of its fundamental principles. The outlined new model of the railway sector functioning in the Member States was, for the most part, revolutionary and at the same time general enough that a number of questions and doubts arose. The revolution in the new model consisted in particular in recommending the separation of railway infrastructure from "old" railway undertakings and establishing new management rules for this railway segment. In addition, a number of doubts arose in relation to the principles of establishing, calculating and charging for access to railway infrastructure. 
After several years of discussions and preparations, in order to facilitate the implementation of the provisions of Directive 91/440, the Council of the European Communities adopted on June 19, 1995, inter alia, directive number 95/19, which concerned the allocation of railway infrastructure potential and charging for infrastructure. The provisions of this directive, however, did not bring any new elements as to the rules for calculating access rates to railway infrastructure, as compared to Directive 91/440. There was still no precise definition of what cost categories should be included in the calculation of infrastructure access rates, and which should not. In addition, there was no known catalog of potential discounts that can be granted to users of railway infrastructure and the rules for granting these concessions. Such a situation of under-regulation gave rise to justifiable demands from the European Commission in order to establish new, more precise rules regarding fees for access to railway infrastructure.

\section{Directive 2001/14}

Finally, Directive 95/19 was repealed by Directive 2001/14 / EC of the European Parliament and of the Council of 26 February 2001 on the allocation of railway infrastructure capacity and charging for the use of railway infrastructure and the granting of safety certificates adopted under the so-called the first railway package. Art. 7, par. 3 of Directive 2001/14, states that '... the fees for the minimum access package and track access to operating equipment shall be determined at the cost which is directly incurred as a result of the operation of the train service.'

The implementation of this provision and maintaining the principle that it is the Member States themselves determine the specific tariff rules for rates, caused that in 20012012 individual countries introduced systems for calculating access rates to railway infrastructure based on their own interpretations of the term "cost" is directly incurred as a result of transporting trains ". It should be emphasized that the European Commission used for its own interpretation of this concept, far different from the positions of many member states, which led to trial processes by the Court of Justice of the European Union, which the European Commission brought in October 2010 against Poland and several other countries.

\section{Case C-512/10 against Poland}

The proceedings before the Tribunal in this matter were based on the European Commission's complaint that Poland did not implement the principle resulting from Directive 2001/14 according to which "the fees for the minimum access package and track access to operate the equipment will be determined at the cost which is directly incurred as a result of operating train services "(Article 7, paragraph 3). According to the Commission, the quoted reference referred to the concept of "marginal costs", which only means costs that arise as a result of actual travel and transport, not fixed costs, which in addition to the costs related to travel and transport, also the costs of the overall operation of the infrastructure, incurred even if the train ride does not take place. As part of the pending proceedings, the Polish party argued that the Polish statutory provisions accurately reflect the provisions of Directive 2001/14. On the other hand, the Commission's claim that "the direct cost incurred as a result of operating train services" is "marginal cost" as unfounded by the Polish side and stressed that, especially in the absence of the EU definition of this first concept, the Member States have a certain freedom to determine what it is included in such direct cost and the number of fees for access to railway infrastructure based on it.

The Advocate General of the Tribunal did not share the European Commission's position regarding the restrictive - in his opinion - view as to the equality of the category of "marginal costs" and "direct costs incurred as a result of operating train services". He also expressed the view that an attempt to give the exact legal meaning of this concept of EU law 
is unnecessary, as it is a concept in the field of economic sciences, the use of which causes serious practical difficulties. He also acknowledged the correctness of Polish statutory provisions regarding the calculation of rates. However, the Ombudsman raised a different argument. He questioned the definition in the implementing provisions of the Act on railway transport of the base for calculating rates, which - in the alternative to the Act - was included in the Regulation of the Minister of Infrastructure and stated that these provisions inevitably lead to consideration when determining the fee charged for the minimum access package and for access to devices related to train service, costs that cannot be considered as direct costs incurred as a result of operating train services. In particular, in the Defender's view, the costs of maintaining or operating railway traffic mentioned in the executive regulations can only partly be considered as costs directly incurred as a result of operating train services, as they include fixed costs that must be borne by the manager after the railway network has been allowed to move, if the train journey does not take place, however, the financial costs remain unrelated to the train service. The summary of the position of the Advocate General was a statement that the Republic of Poland infringed the relevant provision of Directive 2001/14.

\section{Recast of the first railway package - Directive 2012/34}

At the time when the trials filed by the European Commission in 12 Member States were pending due to the violation of the rules of the first railway package, including Poland regarding irregularities in the calculation system of access rates to railway infrastructure, intensive work on the so-called modification of the first railway package. On November 21, 2012, the European Parliament and the Council adopted Directive 2012/34 on the creation of a single European railway area. In art. 31, par. 3 of the directive contains a modified provision regarding the cost category on which the access rates to the railway infrastructure should be based, in the wording: ,... the fees for the minimum access package and for access to the infrastructure connecting the service infrastructure facilities are determined at the cost which is directly incurred as a result of the train journey". In comparison with the analogous provision of Directive 2001/14, the change involved only the obligatory inclusion in the calculation systems of fees for "access to the infrastructure connecting infrastructures", while the category "cost directly incurred as a result of the passage of the train" remained unchanged. In view of this, it can be concluded that the adoption of Directive 2012/34 no longer had any relevance for the Luxembourg trial against Poland. On the other hand, the Directive announced the adoption by the Commission, before 16 June 2015, of the rules for calculating costs which are directly incurred as a result of operating trains. This meant setting a deadline in which the European Commission undertook to specify in more detail the uniformly binding all member countries, the principles of the system of calculating access rates to railway infrastructure.

\section{The judgment of the EU Court of Justice of May 30, 2013}

The Court of Justice has finally ruled that "allowing, in the calculation of the fee for a minimum access package and access to equipment related to train servicing, taking into account costs that cannot be directly incurred as a result of operating train services, the Republic of Poland has failed to fulfill obligations which it is binding under Article 7 par. 3 of Directive 2001/14 / EC of the European Parliament and of the Council of 26 February 2001 on the allocation of railway infrastructure capacity and charging for the use of railway infrastructure and the granting of safety certificates as amended by Directive 2004/49 / EC of the European Parliament and of the Council of April 29, 2004. "The judgment challenged the Polish system of calculation of access rates to railway infrastructure, which could be defined as a result calculation system. In this system, the starting point for the calculation of access rates were the total costs of providing infrastructure access services, from which the amount 
of the "substitute" budget subsidy, specifically financing a part of these costs, was subtracted, thus defining the so-called calculation costs, i.e. the part of costs which was later divided by operation work in order to determine the level of unit rates.

It is also worth citing some guidelines for the construction of the calculation system of access rates to the railway infrastructure that result from the justification of the Award. According to the Court:

- costs related to signaling, traffic, maintenance, and repairs may differ, at least in part, depending on the traffic volume and as a result, may be considered as costs that are directly incurred as a result of the operation of train services,

- to the extent to which they include fixed costs related to the entry into service of a section of the railway network that must be borne by the manager, even if the train does not pass, the costs of maintaining or operating railway traffic ... should be considered as only partially directly incurred costs as a result carrying out train services,

- indirect costs and financial costs ... obviously have no direct connection with the operation of train services,

- to the extent to which depreciation is not made on the basis of actual infrastructure consumption resulting from rail traffic, but in accordance with accounting principles, it also can not be recognized as resulting directly from the operation of train services.

It can be noticed that the general rule of the calculation system of access rates to the railway infrastructure, in the light of the Judgment, completely disregards the number of budget subsidies granted to the infrastructure manager. Therefore, it should be recognized that the costs included in the rate calculation, their type and scope is a completely autonomous issue in relation to the budget subsidy for infrastructure maintenance. The latter should be granted to the administrator on a separate basis, however EU law does not introduce any more restrictions here, indicating only that the state should conclude contracts with the infrastructure manager covering periods of not less than three years, providing for state financing, but in contracts it is also obligatory to have so-called incentives to reduce the costs of providing infrastructure and the size of access charges.

The Court of Justice, by its very nature of its competences, dealt with the law and avoided taking a stand on the economics of infrastructure managers, but nevertheless, it was not entirely able to move away from the economic problems. Although he rejected the category of "marginal costs" promoted by the European Commission as a base for rate calculations, he introduced into the legal cycle the economic category of "fixed costs" incurred as a result of performing train services that can not be included in the rate calculation and "other costs" incurred as a result of performing train services, which are to be the basis for calculating rates. Thus, although indirectly, the Court pointed to the category of "variable costs" incurred as a result of operating train services as a basis for calculation of access rates to railway infrastructure. On the other hand, the fact that in economics the theoretical concept of "marginal cost" understood as the increase in total costs resulting from the increase in production per unit is tantamount to a practical category appearing in enterprises in the form of a "unitary variable cost" of production is a completely different matter. The theoretical category of economics referred to as "marginal cost" is, in the practice of the functioning of enterprises, the amount equivalent to the category of "unitary variable cost" considered in a short period of time. Because the change in total costs in the short term can only be caused by a change in the total variable costs, therefore marginal (marginal) costs can be defined as the increase in total variable costs by unit.

In connection with the introduction (indirectly) of the principle of calculation of access rates to railway infrastructure based on the category of direct variable costs incurred as a 
result of performing train services, which are in fact marginal costs, some substantive difficulties may be expected with the correct implementation of new rules calculating the access rates to the railway infrastructure according to the Judgment of the Court of the Justice, not only in Poland, but also in other European Union member states, as long as the European Commission strives for the universal application of these principles. It can also be assumed that until the concept of "costs that are directly incurred as a result of running trains" is harmonized at the level of the whole European Union, access rate calculation systems, declaratively based on direct costs, but shaped individually in depending on the internal policy of a given country and financial possibilities of subsidy coverage of other, uncovered from the rates, operating costs of infrastructure managers.

\section{Implementing Regulation 2015/909}

In connection with the indicated doubts, some hopes were associated with the new European Commission Regulation, which was to be issued on the basis of the delegation included in Directive 2012/34 ("rework" of the first railway package), where the Commission should precisely define the concept of "costs that are incurred directly as a result of passing the train ". The regulation has been issued, is binding in its entirety and has been directly applicable since 1 August 2015 in all Member States. However, this Regulation is disappointing with the adopted method of defining the most important access tariffs for the cost category railway infrastructure for the current calculation system. It states that, firstly, as in Directive 2012/34, 'direct cost' means the cost that is directly incurred as a result of the passage of the train and, secondly, that 'direct costs across the entire network are calculated as the difference between costs providing services of a minimum access package and access to infrastructure connecting service facilities on the one hand, and on the other hand non-eligible costs "see Table 1. In turn, non-qualified costs are recorded using the phrase "in particular", i.e. in a non-exhaustive manner, a list of a dozen items not eligible for direct costs, headed by the heading "fixed costs related to the provision of a section of the line that the infrastructure manager must incur even in the absence of train traffic "- see Table 2. In this way, the quoted regulation regarding costs, which are incurred directly as a result of the train passage and which are the foundation of the entire rate calculation system, does not fully resolve anything, leaving the Member States still a large margin of their own interpretation of these provisions, but also and potentially exposing them to possible litigation in the future. An additional factor that gives a wide interpretation possibility of the principles of calculating the access rates to the railway infrastructure is a wide catalog of potential criteria for differentiating these rates - see table 3 . 
Tab. 1. Definitions of costs included in the calculation of fees for access to railway infrastructure

\begin{tabular}{|c|c|}
\hline The type of cost & Definition \\
\hline Direct cost & The cost that is directly incurred as a result of the train passing. \\
\hline Direct unit cost & $\begin{array}{l}\text { Direct cost per train kilometer, vehicle kilometer, train gross tonne kilometer } \\
\text { or their combination. }\end{array}$ \\
\hline $\begin{array}{l}\text { The direct costs of the entire } \\
\text { network }\end{array}$ & $\begin{array}{l}\text { Direct cost per train kilometer, vehicle km, a difference between the costs of } \\
\text { providing services with a minimum access package and access to } \\
\text { infrastructure connecting service infrastructure facilities on the one hand, and } \\
\text { on the other hand non-eligible costs. In particular, the following costs for } \\
\text { train gross tonnekilometers or combinations thereof: } \\
\text { - costs of personnel necessary to ensure the operation of a given line } \\
\text { segment, if the applicant asks to perform a given train service } \\
\text { beyond the normal opening hours of this line, } \\
\text { costs of this part of the point infrastructure, including turnouts and } \\
\text { intersections, which are exposed to wear as a result of passing the } \\
\text { train, } \\
\text { part of the costs of overhauls and maintenance of the overhead or } \\
\text { electrified line of the third rail and the auxiliary equipment of the } \\
\text { overhead line, directly incurred as a result of the train service, } \\
\text { staff costs necessary to prepare the allocation of train paths and } \\
\text { timetables, to the extent they are directly incurred as a result of the } \\
\text { train journey. }\end{array}$ \\
\hline $\begin{array}{l}\text { Average direct unit costs for the } \\
\text { entire network }\end{array}$ & $\begin{array}{l}\text { Direct costs across the whole network divided by the total number of forecast } \\
\text { or actual vehicle kilometers, train gross tonne kilometer. }\end{array}$ \\
\hline
\end{tabular}

Source: Commission Implementing Regulation (EU) 2015/909 ..., op. cit. 
Tab. 2. Costs obligatorily not included in the calculation of access rates to the railway infrastructure

\begin{tabular}{|c|c|}
\hline Ineligible costs & 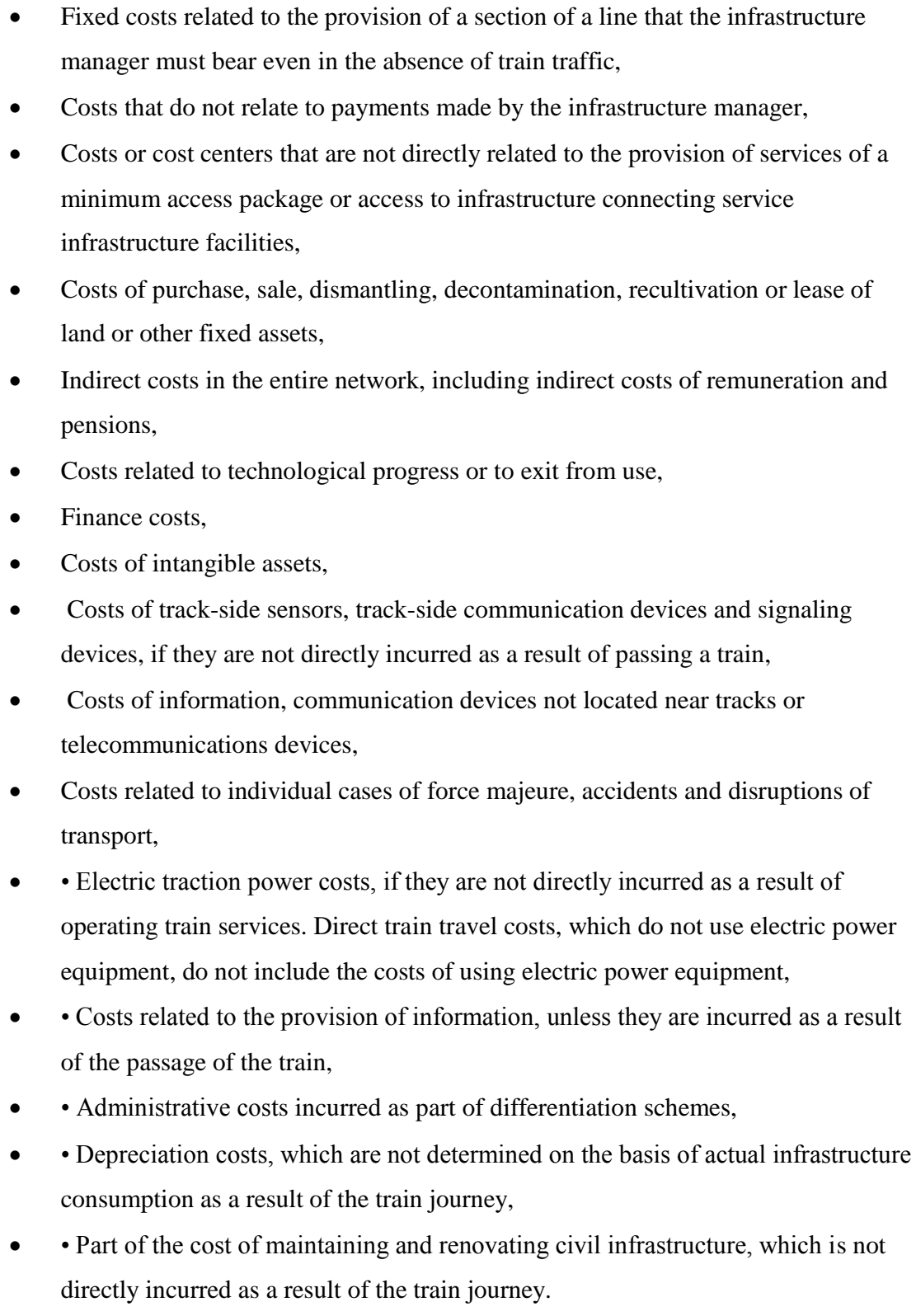 \\
\hline
\end{tabular}

Source: Commission Implementing Regulation (EU) 2015/909 ..., op. cit. 
Tab. 3. Differentiation of direct unit costs for the purpose of calculating the fee for access to railway infrastructure

\begin{tabular}{|c|c|}
\hline $\begin{array}{l}\text { Parameters for differentiating average direct unit } \\
\text { costs in order to take into account different levels } \\
\text { of infrastructure consumption }\end{array}$ & $\begin{array}{l}\text { - the length of the train or the number of vehicles on } \\
\text { the train } \\
\text { - train weight, } \\
\text { type of vehicle, especially its unsprung weight, } \\
\text { - } \quad \text { train speed, } \\
\text { - } \quad \text { axle load or number of axles, } \\
\text { recorded number of wheels with flat seats or } \\
\text { effective use of equipment to protect against } \\
\text { wheel slip, } \\
\text { longitudinal rigidity of vehicles and horizontal } \\
\text { forces affecting the track, } \\
\text { used and measured electrical energy or dynamics } \\
\text { of pantographs or skimmers as a parameter of the } \\
\text { payment for the consumption of an overhead or } \\
\text { electrified rail, } \\
\text { track parameters, in particular turn radii, } \\
\text { any other cost related parameters, if the } \\
\text { infrastructure manager can demonstrate to the } \\
\text { regulatory authority that the values for each } \\
\text { parameter, including where relevant changes } \\
\text { within each parameter, are objectively measured } \\
\text { and recorded. }\end{array}$ \\
\hline
\end{tabular}

Source: Commission Implementing Regulation (EU) 2015/909 ..., op. cit.

It seems that the big paradox in the entire case described above is the fact that on the one hand the Court in its judgment against Poland questioned the so-called the resultant determination of direct costs incurred as a result of the train journey (total infrastructure manager costs minus the budget subsidy used to cover, other than direct costs) and did not even mention that such a fact occurred in Poland while examining the Commission's complaint. On the other hand, in 2015 the Commission introduced an implementing regulation, in which "direct costs incurred as a result of the train journey" are calculated using the output method (total costs of the rail infrastructure manager minus ineligible costs, i.e. those costs to be covered and thus financed, budget subsidy). It can, of course, be claimed that the Polish system required the inclusion of the subsidy amount with this calculation, ie an element related to the transport policy undoubtedly, and the system set out in Commission Regulation 2015/909 requires the inclusion of exhaustively listed cost items as costs to be covered by subsidies, i.e. it is potentially better, more precise and appropriate and compliant with EU law, but it does not change the fact that it is a resultant which was previously questioned by the Court. 